\title{
Spoken English Errors of Undergraduate Students in Selected Tertiary Institutions in Southeastern Nigerian
}

\author{
Ngozi U. Emeka-Nwobia ${ }^{1}$, Mercy Agha Onu ${ }^{2}$ \\ ${ }^{1,2}$ Department of Linguistics and Literary Studies, Ebonyi State University, Abakaliki - Nigeria
}

\begin{abstract}
This paper examines spoken English errors of undergraduate students of selected tertiary institutions in southeastern Nigeria. The data draws from community of informants in randomly selected Universities, Polytechnics and Colleges of Education located in Enugu and Ebonyi states of Nigeria. The respondents aged between 18 and 25 constitute the representative population. Findings reveal that mother tongue interference is a common phenomenon in the spoken English of some educated population of Nigerian second language speakers of English. Some are unconsciously displayed by the speakers while others are not. Notwithstanding that tertiary institution students in Nigeria constitute an educated class who must have been exposed to written and spoken English for about twelve years in the primary and secondary schools, respondents still displayed predominantly the error of substitution, where some English phonemes which do not exist in Nigerian languages were replaced with the ones they have in their various languages or dialects. These substitutions could lead to distortion in communication and meaning especially in communications involving non-speakers of Igbo language.
\end{abstract}

Keywords: Error Analysis, Second language, Phonemes, Communicative Competence

\section{INTRODUCTION}

The place of English Language in Nigeria transcends that of official communication used for international purposes, it is used as the national official language and as the first language of some Nigerians. Its usage permeates into the national foci where it serves as the lingua franca of the nation as well as the language of the three tiers of government. English is the language of education, legislature, judiciary, media, etc. it has maintained an exalted status in Nigeria even after fifty six years of independence. This extolled position is principally attributed to the linguistic heterogeneity of Nigeria which is so unique that no indigenous language could be acceptable to all the existing linguistic groups without raising the dust of ethnic antagonism. Nigeria is a nation state characterized by diverse ethno linguistic groups. As such a term of unity is of utmost importance, hence English is considered a language of unity which unites the different ethno- linguistic groups as one entity. Again, no Nigeria language has acquired enough frames of reference and elaborated code to match up with modern linguistic needs of the people. English provides a means by which Nigerians just like others can participate in the present competitive modern world. One's level of communicative competence in English language determines his placement in the society likewise, his access to the white-collar job

In spite of its highly extolled status and the number of years of its usage in Nigeria, its use among the so called educated members of the society is still with prevalent errors. These errors are usually ascribed to mother tongue interference. It is unfortunate to note that in spite of this pervasive situation, the study of oral English has received less patronage when compared with the study of its grammatical forms.

This study therefore examines the Spoken English errors of Undergraduate students in selected tertiary institutions in south eastern Nigerian. The choice of undergraduate students is because they are envisioned by the society as belonging to the educated class and should possess adequate language skills in the spoken English.

The study anchors on error and contrastive analysis.

\section{THEORETICAL FRAMEWORK}

The work is anchored on Error Analysis. In terms of second language learning, error analysis has a long history. It was established in the 1960 s by Stephen Pit Corder and colleagues as an alternative to contrastive analysis, which is a sub discipline of linguistics interested in the comparison of two or more languages or subsystems of language in order to determine both differences and similarities between them. It is an indispensible component of a second language learning model which reliably forecasts that the speaker of an arbitrary first language is liable to produce grammatically deviant second language sentences, the structural descriptions of which will resemble those of analogous first language sentences. Carl (1971).

The study of Error Analysis emerged as a branch of Applied Linguistics to reveal that learner errors were not as a result of the learner's native language but rather a depiction of some universal strategies. This is a 
reaction to Contrastive Analysis Theory which considered native language interference as the major source of errors in second language learning, which is in line with the behavioristic theory. Corder (1967) mentions the paradigm shift in linguistics from a behaviouristic view of language to a more rationalistic view and claims that in language teaching, one noticeable effect is to shift the emphasis away from teaching towards study of learning. Error analysis showed that contrastive analysis was unable to predict a great majority of errors, although its more valuable aspects have been incorporated into the study of language transfer. (Corder, 1974: 125) states that, The study of error is part of the investigation of the process of language learning. In this respect it resembles methodologically the study of the acquisition of the mother tongue. It provides us with a picture of the linguistic development of a learner and may give us indications as to the learning process.

Error analysis acts as a bridge between the adult native speaker of a language and a second language learner of a language. Its concern is on the differences between the way people learning a language speaks and the way the adult native speakers of the language utilize the language. It is interested in understudying the differences with the primary aim of identifying learners errors, outlining the causes and significance of such errors in the speeches of the second language learners.

Erdogan (2005) delved further to define the concept of Applied Error Analysis on the other hand, as interested in "organizing remedial courses and devising appropriate materials and teaching strategies based on the findings of theoretical error analysis". Corder (1987) captures the significance of learners' errors in three different ways; first to the teacher in that they tell him, if he undertakes a systematic analysis, how far towards the goal the learner has progressed, and consequently what remains for him to learn. Second, they provide to the researcher evidence of how language is learned or acquired, what strategies or procedures the learner is employing in his discovery of the language. Thirdly, (and in a sense this is their most important aspect) they are indispensable to the learner himself, because we can regard the making of errors as a device the learner uses in order to learn.

Brown (1993) notes that the surge of the study of learners' errors otherwise called error analysis stemmed out because learners make errors and these errors can be observed, analyzed and classified to reveal something of the system operating within the learner. He differentiates between mistakes and errors, noting that a mistake refers to a performance error that is either a random guess or slip in that it is a failure to utilize a known system correctly. Everybody is bound to make mistake at both native and second language situations. Native speakers are normally capable of recognizing and correcting such mistakes, which are not the result of a deficiency in competence but the result of some sort of breakdown in the process of production. Mistakes could occur as a result of fatigue, excitement, etc. and therefore can be readily self-corrected. Error on the other hand is a noticeable deviation, reflecting the competence of the learner. It is a systematic deviation made by the learner who has not yet mastered the rules of the target language. The learner cannot self correct an error because it is a product reflective of his or her current stage of L2 development, or underlying competence (Larsen, 1992: 59). Error analysis is the study of kind and quantity of error that occurs, particularly in the fields of applied linguistics. These errors can be divided into three sub-categories: overgeneralization, incomplete rule application, and the hypothesizing of false concepts, reflected a learner's competence at a certain stage and thereby differed from learner to learner. Hence, only the teacher or the researcher would locate them, the learner would not (Gass \& Selinker, 1994).

This paper seeks to examine not the entirety of error, but the phonological errors of the spoken English of some Nigerians who use English as a Second language. The Nigerians whom this work focuses on are undergraduate students of universities, polytechnic and colleges of education located in Ebonyi and Enugu states. This study is imperative because in Nigeria and in most African societies language teachers, and the educated populace in general, are expected to speak the error free version of English language, due to the level of training and exposure given to this group of Nigerians. Unfortunately, some of undergraduates in Nigerian tertiary institutions even those studying English language are susceptible to errors and still commit blunders in their spoken English. These errors range from interference to inter- language, and they are capable of being committed by any second language speaker, irrespective of one's level of competence or training. Educated second language learners of English are potentially to be influenced by the environment/ contexts of speakers around him or her which in turn made him commit errors of some sort. This is capable of distorting effective communication. Onuigbo (1984) succinctly observes that in first language learning, the learner is highly motivated and is surrounded by conducive linguistic environment, the kind that the second language users lack. This implies that though language learning generally has some problems, second language learning has greater problem than first language learning. This problem results in a greater number of errors in the performance of the second language users. For this reason, theorists in language teaching and learning and use, have come up with two different approaches to examine these errors. These approaches are Contrastive Analysis and Error Analysis.

The purpose of this study is to act as enlightenment to the second language learners of English, students and teacher on the existence of such phonological lapses and the way forward to address such 
problems. The work will as well help second language teachers, since they are the foundation layers of all second language learning. This work shall as well act as a feedback tool to Second Language (L2) learners and speakers of English language in general, on how to produce sounds of English language that are phonologically error free.

\section{DATA}

The study is a survey that examined the spoken English errors committed by undergraduate students in tertiary institution in selected schools in Ebonyi and Enugu states. The data was drawn from different sessions of conversational exchanges. Below are the predominant errors prevalent in their speeches.

Table 1: Substitution of the voiceless alveolar plosive $/ t /$, for the voiceless interdental fricative $/ \theta /$ For instance the following words were pronounced:

\begin{tabular}{|c|c|c|}
\hline Word & Correct Pronunciation & Rendition \\
\hline Fifth & $/$ fift $/$ & /fift/ \\
\hline Month & $/ \mathbf{m} \Lambda \mathbf{n t \theta} /$ & /mont/ \\
\hline Theme & $/ \boldsymbol{\theta i}: \mathbf{m} /$ & /tim/ \\
\hline Thing & $/ \boldsymbol{\theta i n} /$ & /tin/ \\
\hline $\begin{array}{l}\text { Thought } \\
\text { With }\end{array}$ & 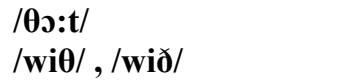 & $\begin{array}{l}\text { /to:t// } \\
\text { /wit/ }\end{array}$ \\
\hline
\end{tabular}

Table 2: Substitution of the voiced alveolar plosive /d/, for the voiced interdental fricative /ð/

\begin{tabular}{|l|l|l|}
\hline Word & Correct Pronunciation & Rendition \\
\hline Mother & $/ \mathbf{m} \Lambda$ ðə/ & $/ \mathbf{m o d a} /$ \\
\hline Then & $/$ /en/ & $/ \mathbf{d e n} /$ \\
\hline
\end{tabular}

Table 3: The Substitution of the voiceless post alveolar fricative $/ 3 /$, for the voiced post-alveolar affricate / ds /

\begin{tabular}{|l|l|l|}
\hline Word & Correct Pronunciation & Rendition \\
\hline Leisure & $/$ le3ə/ & $/$ lidgə/ \\
\hline Pleasure & $/ \mathbf{p l e 3 ə /}$ & $/ \mathbf{p l e d g} /$ \\
\hline Major & $/ \mathbf{m e i d g} /$ & $/ \mathbf{m e d g} /$ \\
\hline Measure & $/ \mathbf{m e 3 ə /}$ & $/ \mathbf{m e j} /$ \\
\hline
\end{tabular}

Table 4: The Substitution of the voiceless post-alveolar fricative / $\int /$, for the voiced post alveolar affricate / $t /$ and vice versa;

\begin{tabular}{|c|c|c|}
\hline Word & Correct Pronunciation & Rendition \\
\hline China & /tgainə/ & /Jaina/ \\
\hline child & /tgaild/ & /Jaild/ \\
\hline Matching & /matfin/ & /mæfin/ \\
\hline Shoot & / $\mathbf{f u}: \mathbf{t} /$ & $/$ tfu:t/ \\
\hline Shout & / Jaot/ & /faot/ \\
\hline Short & $/ \mathbf{j} \mathbf{j}: \mathbf{t} /$ & /ffo:t/ \\
\hline
\end{tabular}

Table 5: Substitution of voiceless alveolar fricative/s/ for voiced alveolar fricative /z/

\begin{tabular}{|l|l|l|}
\hline Word & Correct Pronunciation & Rendition \\
\hline Charges & /tga:rdziz / & / ta:dzis / \\
\hline Lapses & /læpsiz/ & /ææsis/ \\
\hline Was & /woz/ & /wos/ \\
\hline Has & /hæz/ & /hæs/ \\
\hline details & /di:teilz/ & /di:teils/ \\
\hline services & /s3:visiz/ & /s3:visis/ \\
\hline resources & /rizo:siz/ & /rizo:sis/ \\
\hline
\end{tabular}

TABLE 6: Substitution of voiced alveolar plosive /d/ for voiceless alveolar plosive /t/

\begin{tabular}{|c|c|c|}
\hline Word & Correct Pronunciation & Rendition \\
\hline Addressed & /o'drest/ & /o'dresd/ \\
\hline Announced & /o'nautst / & /o'nautsd/ \\
\hline Cherished & $/$ tferift/ & $/$ tferifd/ \\
\hline
\end{tabular}




\begin{tabular}{|l|l|l|}
\hline Expressed & /ik'sprest/ & /ik'spresd// \\
\hline Pleased & /pli:zd/ & /di:teils/ \\
\hline services & /s3:visiz/ & /pli:zd// \\
\hline Promised & /promist/ & /promisd/ \\
\hline Asked & /a:skt/ & /a:sd// \\
\hline
\end{tabular}

TABLE 7: Substitution of / a / for schwa / a /

\begin{tabular}{|l|l|l|}
\hline Word & Correct Pronunciation & Rendition \\
\hline Attack & /ə'tæk/ & /atak/ \\
\hline water & /wo:tə/ & /wota/ \\
\hline
\end{tabular}

TABLE 8: Substitution of / ou / for /o/

\begin{tabular}{|l|l|l|}
\hline Word & Correct Pronunciation & Rendition \\
\hline Go & $/$ gəo/ & $/$ go: / \\
\hline So & $/$ səo/ & $/$ so: / \\
\hline Follow & $/$ fələo / & $/$ folo/ \\
\hline
\end{tabular}

TABLE 9: Substitution of / 3: / for / ॰: /

\begin{tabular}{|c|c|c|}
\hline Word & Correct Pronunciation & Rendition \\
\hline curb & $/ \mathrm{k} 3: \mathrm{b} / /$ & / ko:b/ \\
\hline Colonel & / k3:nl/ & / ko:nəl/ \\
\hline Occurred & /ə'k3:d/ & /əko:d/ \\
\hline Urged & $/ / 3: d \mathbf{d} d /$ & /o:dgd/ \\
\hline Disbursed & /disb3:st/ & / disbo:sd/ \\
\hline Worshiped & /w3:Jipt/ & /wo:Jipd/ \\
\hline
\end{tabular}

\section{DISCUSSION}

In most speeches recorded, speakers displayed high degree of occurrence in the substitution of the voiced and voiceless inter dental affricate with the voiceless alveolar plosive / $\mathbf{t} /$. This prevalence in the substitution is because the voiced and voiceless interdental affricates are not present in the sounds of any Nigerian language. Learning of its use is always met with difficulties by second language learners because the two sounds are not part of the Nigerian language phonology, and therefore alien to Nigerian second language speakers of English. This leads to the replacement of the sound to the closest sound at the point of articulation. Thus / $\boldsymbol{\theta}$ / is replaced with / t / and / ठ/ replaced with/ $\mathbf{d} /$.

In table 3 , the voiced post-alveolar fricative /3/ was realized as its voiceless counterpart / $\mathbf{j} /$ or sometimes as voiced post-alveolar affricate / d $/$. This sound was equally problematic among the Igbo language speakers of English as second language. Most of them unconsciously switched from one of the sounds to another.

Another error identified, was the inconsistencies in the placement of the voiceless post alveolar affricate $/ \mathbf{t} /$ and the voiceless post-alveolar fricative / $\mathbf{J}$. Some of the subjects were confused as they grapples with inadequate knowledge of where each should occur or be used.

In Table 5, the voiceless alveolar fricative /s/ and its voiced counterpart /z/ were sometimes used interchangeably. It is noteworthy, that most of the rules regarding the use of $/ \mathbf{s} /$ and /z/ sounds as plural markers/suffixes are so complicated and subject to numerous exceptions. Most people, who commit the errors outlined in Table 6, are not familiar with the English phonological rule which states that when a verb ends in /d/ or in $/ \mathbf{t} /$, the termination is pronounced /d/; but when the verb ends with a voiceless consonant other than /t/, the termination is pronounced $/ \mathbf{t} /$.

The errors of substituting /ou/ for /o/ occurrence are visible because the subjects were not adequately exposed to the right model of English language. / 3: / was equally substituted for /o: /, probably because the sound / 3: / does not exist in any Nigerian language, moreover not all undergraduate students are adequately exposed to the right model of English language phonology.

\section{CONCLUSION}

Findings reveal that due to the fact that English language is full of rules and exceptions which are too numerous, sometimes complicated and subject to exemptions. A second language or non indigenous speaker of English may find it difficult to articulate some of the English sounds in certain environment correctly. A speaker of English should strive to learn the individual pronunciation of each word as he encounters them daily. It was observed that our subjects grossly committed the error of substitution by replacing sounds certain English 
sounds which are not available in the first language with the ones that were found in their various languages.

\section{REFERENCES}

[1] S.A. Aladeyomi and A.K. Adetunde, 2007. Errors of Segemental Phonemes in the Spoken English of Nigerian Television Newscasters. The Social Sciences, 2: 302-306.

[2] Agbedo, CU(2000). General Linguistics: An Introductory Survey. Nsukka: ACE Resource Konsult.

[3] Akmajian, A. Demers, A.R. and Harnish, R.M. (2008). An Introduction to Language and Communication. India: Prentice Hall.

[4] Aladeyomi, SA(2003). An Evaluation of the Spoken English Performance of Nigerian Television newscasters. An unpublished $\mathrm{PhD}$ thesis, University of Ibadan.

[5] Aladeyomi, S. A. and Adetunde, A. K. (2007). "Errors of Segmental Phonemes in the spoken English of Nigerian Television Casters". The Social Sciences 2(3):302-306, Medwell Journals.

[6] Brown, H.D. (1987). Principles of Language Learning and Teaching. Englewood Cliffs. N.J. Prentice Hall.

[7] Brown, H. Douglas. (1993). Principles of Language Learning and Teaching. San Francisco: Prentice Hall Regents

[8] Burt, M, Dulay, H. and Krashen, S. (1982). Language Two. New York. Oxford University Press.

[9] Clark, J. Yallop, C. and Flecher, J. (2007). An Introduction to Phonetics and Phonology. U.K: Blackwell Publishing.

[10] Corder, S. (1973). Introducing Applied Linguistics. London: Penguin Books.

[11] Corder, S.P. (1974). Error Analysis in Allen, J.L.P. and Corder, S.P. (eds) Techniques in Applied Linguistics. Oxford. Oxford University Press.

[12] Corder, S.P. (1981). Error Analysis and Interlanguage. Oxford. Oxford University Press.

[13] Erdogan, V. (2005). Contribution of Error Analysis to Foreign Language Teaching. Mersin University Journal of the Faculty of Education. 2, 261-270.

[14] Fisiak, J. (1981). Contrastive Linguistic and the Language Teacher. Oxford: Oxford Pergamon Press

[15] Hyman, L.M. (1975). Phonology: Theory and Analysis. USA Holt Rhinehart and Winston.

[16] Lado, R. (1957). Linguistics across cultures: Applied linguistics for language teachers. University of Michigan Press: Ann Arbor

[17] Larsen, Diane, et al. (1992). An Introduction to Second Language Acquisition Research. London: Longman

[18] Olasehinde, MO(2002). "Error Analysis and Remedial Pedagogy". In Babatunde,

[19] S.T. and D.S. Adeyanju, (Eds.), Language, Meaning and Society. Ilorin: Haytee Press and Publishing Co. Nigeria, Ltd

[20] Osisanwo, A. (2009). Fundamentals of English Phonetics and Phonology. Nigeria: Femolus Fetops.

[21] Oyebade, F. (1998). A Course Book in Phonology. Nigeria: Shebiotimo Publication.

[22] Roach, P. (2000). English Phonetics and Phonology. UK: Cambridge University press.

[23] Schackne, Steven. (2002). Language Teaching Research.In. Journal of Language and Linguistics. Volume 1 Number 2 , ISSN $1475-8989$ 